\title{
THE TITRATABLE ACIDITY, pH, AMMONIA AND PHOSPHATES IN THE URINES OF VERY YOUNG INFANTS
}

\author{
BY \\ R. A. MCCANCE and M. A. von FINCK \\ (From the Medical Research Council, Department of Experimental Medicine, Cambridge, \\ England; and Wuppertal, B.A.O.R.)
}

It has now been established that for some time after birth the kidney is still functionally immature. In many respects its actions differ from those of the same organ in adult life. This is but one aspect of the physiology of infancy, but it is an important one in clinical medicine, and so illuminating have the findings been that there is every reason to prosecute further studies of the organ in the early days of life. It has already been shown that the glomerular filtration rate, the urea, and the sodium and chloride clearances are very low in newborn babies, and that very young animals are unable to concentrate their urines to the same extent as adults of the same species. These and other aspects of the subject were reviewed by McCance (1946); and since that time papers have been completed on the excretion of water, urea, and sodium chloride by the newborn rat (McCance and Wilkinson, 1947), and the excretion of diodone and creatinine by infants in the early days of life (Dean and McCance, 1947). There is almost no literature dealing with the subject matter of the present paper, but any pertinent observations will be referred to when the results are being discussed.

\section{Methods}

Samples of urine were obtained from healthy full-term babies born in the Landesfrauenklinik, Wuppertal. The urines passed immediately after birth were procured through the keenness and dexterity of the staff of the labour room; the remainder were collected in the usual way from male infants by strapping a small test tube over the penis. The urines were preserved under toluene in the ice chest for a few hours and were then taken to the I.G.-Farben laboratories where they were examined without delay for $\mathrm{pH}$, titratable acidity, and ammonia. The urines were also analysed for inorganic phosphates, total nitrogen, and sometimes for urea, but it was not always possible to begin these determinations on the day the urines were received. If there was a precipitate of urates in the urines, it was customary to warm them before removing the aliquots for the determinations of the titratable acidity, ammonia, phosphates, and total nitrogen, but the $\mathrm{pH}$ was usually determined before the urine was warmed.

Specimens of urine were also obtained from healthy British men and women and from healthy well nourished Germans. These urines were collected at various times throughout the day. Some were early morning specimens. Aliquots were removed soon after the urines were passed for the determination of $\mathrm{pH}$, titratable acidity, and ammonia, and the remainder of the urine was preserved under toluene if it was not possible to make the determinations of phosphates and total nitrogen forthwith.

Through the co-operation of the staff of the Kamillus Krankenhaus, Essen, some specimens of urine were also obtained from ketosed diabetics. These urines were preserved with toluene and sent to Wuppertal within a few hours, where they were treated in the same way as the other urines.

The $\mathrm{pH}$ was determined colorimetrically by the B.D.H. capillator method. For the determination of the titratable acidity $1 \mathrm{ml}$. of the urine was titrated with $0.01 \mathrm{~N}$ sulphuric acid in a white porcelain dish to $\mathrm{pH} \mathrm{7.4}$. The end point was determined colorimetrically by removing very small drops with a fine glass rod and mixing them with phenol red on a white tile, and was checked by the B.D.H. capillator. Phenolphthalein was then added and the prine further titrated to the first appearance of a pink colour. This was usually $\mathrm{pH} 8 \cdot 3$ to $8 \cdot 4$, and if the urine was coloured or the end point difficult to see this was checked by the capillator using cresol red as the indicator. The ammonia was determined both by formol titration and also in Conway and Byrne (1933) 'units'; $1 \mathrm{ml}$. of $0.01 \mathrm{~N} \mathrm{HCl}$ or $0.01 \mathrm{~N} \mathrm{H}_{2} \mathrm{SO}_{4}$ was placed in the centre chamber and the back titration was carried out with approximately $0.01 \mathrm{~N}$ Baryta, or $\mathrm{CO}_{3}$ free $\mathrm{NaOH}$. The indicator used was a mixture of methylene blue and methyl red (Conway, 1935). 
The result of the formol titration was taken as a rough guide to the quantity of urine to be taken for a gasometric determination of ammonia. All the figures for ammonia given in this paper were obtained by the diffusion method. The phosphates were determined either by the method of Briggs (1922) or of Fiske and Subberow (1925). Both gave the same results, but the latter method required less urine and was generally employed. A Pulfrich step photometer was used for all the colour comparisons. The total nitrogen was determined by the standard micro Kjeldahl procedure. Copper selenide was used to facilitate the digestion and heating was continued for at least one and usually many hours after the mixture cleared. Lee and Widdowson's (1937) method was used for urea. The urine was not always titrated twice to $\mathrm{pH} 7 \cdot 4$, but all other determinations were invariably carried out in duplicate. The proportion of the titratable acidity due to phosphates was determined in the following way : $1 \mathrm{ml}$. of a solution of $\mathrm{KH}_{2} \mathrm{PO}_{4}$ containing $2 \mathrm{mg}$. of $\mathrm{P}$, was treated with small quantities of $0.01 \mathrm{~N} \mathrm{NaOH}$ and the $\mathrm{pH}$ noted after each addition. From the results a curve was constructed showing the number of cubic centimetres of $0.01 \mathrm{~N} \mathrm{NaOH}$ required to titrate from $\mathrm{pH} 5 \cdot 4,5 \cdot 6,5 \cdot 8,6 \cdot 0 \ldots$ to $7 \cdot 4$, and also to the phenolphthalein end point. From this curve, the $\mathrm{pH}$ of the urine, and the amount of $\mathbf{P}$ found in it, it was possible to calculate the contribution of the urinary phosphates to the titratable acidity. In doing so it was assumed that the constituents of the urine other than $P$ did not materially affect its titration. The difference between the total titratable acidity and the titratable acidity due to the phosphates gave the proportion due to organic acids.

The data now to be set out and discussed are based upon the examination of seventy-two urines obtained from sixty-eight infants, forty-three urines collected from thirty-six adults, and ten specimens of diabetic urine. Two of the last came from the same patient, but the second was obtained some months after the first when the man was readmitted to the hospital. The composition of an infant's urine varies so much with its age that for some purposes the babies were divided into the following seven age groups. The first comprised ten babies from whom urine was obtained at or immediately after birth (age 0); the second, ten babies aged 5 to 24 hours; the third, ten babies aged 24 to 72 hours; the fourth, eleven babies between 72 hours and $4 \frac{1}{2}$ days; the fifth, eleven babies, aged $4 \frac{1}{2}$ to 6 days; the sixth, ten babies aged 6 to 7 days; and the seventh, ten babies aged 7 days or older. The majority of the babies in the last group were 7 days old, but two were 8, one 9 and one 12 days of age. The babies were all breast fed and the practice at the Landesfrauenklinik is to give the children nothing by mouth in the first few days of life except mother's milk. They are first put to the breast eighteen to twenty-four hours after birth. Some of the babies in the older age groups were being given a small supplement of half and half 'Haferschleim' and cows' milk.

\section{Results}

pH. Henderson and Palmer (1914) found the average $\mathrm{pH}$ of 222 normal adult urines to be $5 \cdot 98$. The $\mathrm{pH}$ of the seventy-two infant urines averaged $5 \cdot 96$, and of the forty-three adult urines $6 \cdot 11$, which is almost the same, but as the frequency distribution diagram in fig. 1 shows, the $\mathrm{pH}$ values of the infant urines were more closely grouped about the mean than those of the adults, and there were fewer urines

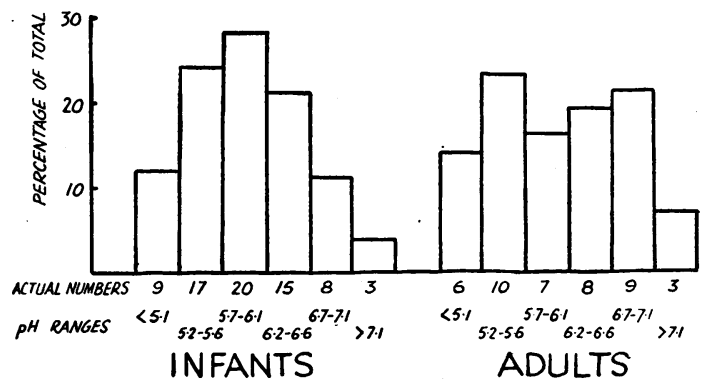

FIG. 1.-Frequency distribution diagrams of the $\mathrm{pH}$ values of infant and adult urines.

in the highest and lowest $\mathrm{pH}$ groups. This may just be an expression of the fact that the adults were subjecting their bodies to greater $\mathrm{pH}$ changes due to their more varied diets and activities, but it may also indicate that the $\mathrm{pH}$ of an infant's urine is not so easily changed by the kidney in response to variations in the $\mathrm{pH}$ of the internal environment.

The $\mathrm{pH}$ of the urine may be affected by the age of the infant. This was pointed out by Ylppö (1916) and by Thomson (1944), some of whose observations have been of great value in working up the present data. The results of the present investigation are given in table 1 . None of the

TABLE 1

CHANGES IN THE pH OF THE URINE DURING THE EARLY DAYS OF LIFE

\begin{tabular}{|c|c|c|c|c|c|}
\hline \multicolumn{4}{|c|}{$\begin{array}{c}\text { Present } \\
\text { data }\end{array}$} & \multicolumn{2}{|c|}{$\begin{array}{l}\text { Thomson's } \\
\text { data }\end{array}$} \\
\hline Age & $\begin{array}{c}\mathrm{pH} \\
\text { average } \\
\text { value }\end{array}$ & Range & $\sigma$ & $\begin{array}{l}\text { Age } \\
\text { days }\end{array}$ & $\begin{array}{l}\text { Average } \\
\text { value }\end{array}$ \\
\hline $\begin{array}{c}0 \\
5-24 \mathrm{hr} . \\
24-72 \mathrm{hr} . \\
72 \mathrm{hr} .-\end{array}$ & $\begin{array}{l}6 \cdot 06 \\
5 \cdot 70 \\
5 \cdot 70\end{array}$ & $\begin{array}{l}4 \cdot 9-6 \cdot 8 \\
4 \cdot 9-6 \cdot 3 \\
5 \cdot 0-6 \cdot 3\end{array}$ & $\begin{array}{l}0.71 \\
0.32 \\
0.45\end{array}$ & $\begin{array}{l}1 \\
2 \\
3\end{array}$ & $\begin{array}{l}5 \cdot 70 \\
5 \cdot 80 \\
6 \cdot 12\end{array}$ \\
\hline $\begin{array}{l}4 \frac{1}{2} \text { days } \\
4 \frac{1}{2}-6 \text { days } \\
6-7 \text { days } \\
7 \text { days }\end{array}$ & $\begin{array}{l}6 \cdot 04 \\
5 \cdot 90 \\
6 \cdot 10\end{array}$ & $\begin{array}{l}5 \cdot 0-7 \cdot 0 \\
5 \cdot 1-6 \cdot 7 \\
5 \cdot 1-7 \cdot 7\end{array}$ & $\begin{array}{l}0.65 \\
0.49 \\
0.82\end{array}$ & $\begin{array}{l}4 \\
5 \\
6\end{array}$ & $\begin{array}{l}6 \cdot 20 \\
6 \cdot 41 \\
6 \cdot 40\end{array}$ \\
\hline and over & $6 \cdot 30$ & $5 \cdot 5-7 \cdot 4$ & 0.76 & 8 & $6 \cdot 58$ \\
\hline
\end{tabular}


differences are statistically significant owing to the large scatter at each age, but the figures do agree on the whole with those of Ylppö and of Thomson, whose average figures taken from the latter's fig. 11 are also given in table 1 . It should be pointed out that Thomson had no group corresponding to the present age 0 , and also that his observations, although showing a very great range of scatter, may be more valuable than the present ones, for they were based upon twenty-four-hour specimens. Thomson also demonstrated similar $\mathrm{pH}$ changes in the day-to-day urines of individual children, and it seems probable that there really is a tendency for the $\mathrm{pH}$ of the urine to rise from the first to the ninth day of life. Thomson's explanation of the phenomenon was that the newly born infants were in a state of acidosis, and, while this may be true, it does not seem a completely satisfactory explanation of the urinary findings. A number of authors have studied the serum chemistry of newborn infants, and some of them have compared their findings with those of adults (Lucas et al., 1921; Hoag and Kiser, 1931; Marples and Lippard, 1932, 1933; Branning, 1942). There is general agreement that the plasma bicarbonate is lower soon after birth than it is in adult life, and that there may be more organic acids in an infant's plasma, but there is no certain evidence that this acidosis corrects itself in the first eight or nine days of life. Hoag and Kiser (1931) stated positively that the plasma bicarbonate level was not affected by age up to the thirteenth day of life. Marples and Lippard (1932) considered that the plasma bicarbonate was lowest on the third day of life, but their figures are unconvincing and not in agreement with those of Lucas et al. (1921).

Ylppö (1916) showed that two days' starvation materially lowered the $\mathrm{pH}$ of the urine in older infants, and babies of one to three days of age must be regarded as being in a state of starvation. This, coupled with the progressive intake of metabolizable food after the second day, may be the explanation of the changes in urinary $\mathrm{pH}$, but there would appear to be another one, and both may operate. The present results have shown that the urine passed at birth, which must have been formed in utero, may have a $\mathrm{pH}$ as high as $6 \cdot 8$, and the average for these specimens is higher than for those of the first and second days of life. These urines passed at birth are always very dilute (see later), but immediately after birth the infant enters a phase of hydropenia and oliguria, and this again is superseded by a period of rehydration and rising urine volumes as the flow of milk is established and increased (Veil, 1923; Thomson, 1944). Henderson and Palmer (1914) found a direct relationship between the $\mathrm{pH}$ and. the volume of 122 twenty-fourhour specimens of adult urine. It is well known, moreover, in adult men and animals who have not taken food for some hours, that if the urine volumes are small the $\mathrm{pH}$ tends to be low and that a diuresis tends to raise the $\mathrm{pH}$ of the urine (Rüdel, 1892 ; Cushny, 1904; Carr, 1921; Briggs, 1942). Eggleton (1946) made similar observations. The same is true of infants (table 2), and it is suggested that the rate at which the urine is formed helps to explain why the $\mathrm{pH}$ of an infant's urine tends to fall for a day or two after birth and then to rise again for the next eight or nine days. It may be pointed out in passing that the $\mathrm{pH}$ of the urines formed in utero did not on the whole suggest that the infants were in a state of acidosis before birth or during that process. Only one of the urines was highly acid, but this may be because the infant's kidney can produce a very acid urine only when the $\mathrm{pH}$ of the internal environment has become highly abnormal. Possibly all infants, however, are able, given the requisite stimulus, to concentrate $\mathbf{H}$ ions in their urines nearly as well as adults, for a number of these infant urines have had $\mathrm{pH}$ values as low as $4 \cdot 9$, which is about the limiting value at any age.

Titratable acidity, total nitrogen, and ammonia. It is important to realize at the outset of any discussion on titratable acidity what the determination sets out to measure and upon what its magnitude chiefly depends. Urine is generally acid, and this is due to the fact that it contains an assortment of weak organic acids such as uric acid, lactic acid, $\beta$-hydroxybutyric acid, etc., and phosphates. The $\mathrm{pH}$ of the urine fixes the proportion of the lastnamed present as the dihydrogen salt, and also what fractions of the other weak organic acids shall be present as their salts, and what fraction as the free acids. The titration of any specimen of urine with $\mathrm{NaOH}$ gives a measure of the free hydrogen ions in it due to all these acids. It does not measure the acid radicles in the urine, most of which may be

TABle 2

EFFECT OF DIURESIS ON pH OF URINE

\begin{tabular}{|c|c|c|c|c|c|c|c|c|c|}
\hline R. A. M. & Age 47 years & $\cdots$ & $\underset{\mathrm{pH}}{\operatorname{Min} .}$ Vol. & $\begin{array}{l}1 \cdot 0 \\
4 \cdot 9\end{array}$ & $\begin{array}{l}2 \cdot 37 \\
5 \cdot 1\end{array}$ & $\begin{array}{l}8 \cdot 9 \\
6 \cdot 0\end{array}$ & $\begin{array}{l}7 \cdot 0 \\
5 \cdot 8\end{array}$ & $\begin{array}{l}2 \cdot 3 \\
5 \cdot 2\end{array}$ & $\begin{array}{l}1 \cdot 6 \\
5 \cdot 0\end{array}$ \\
\hline Baby $\mathbf{R}$. & Age 21 days & $\ldots$ & $\underset{\mathrm{pH}}{\operatorname{Min} .} \mathrm{Vol.}$ & $\begin{array}{l}0 \cdot 0116 \\
5 \cdot 7\end{array}$ & $\begin{array}{l}0 \cdot 0144 \\
5 \cdot 9\end{array}$ & $\begin{array}{l}1 \cdot 04 \\
6 \cdot 6\end{array}$ & $\begin{array}{l}0 \cdot 922 \\
6 \cdot 5\end{array}$ & $\begin{array}{l}0 \cdot 670 \\
6 \cdot 1\end{array}$ & $\begin{array}{l}0.088 \\
5 \cdot 5\end{array}$ \\
\hline Baby $\mathbf{T}$. & Age 16 days & $\cdots$ & $\underset{\text { pH }}{\text { Min. Vol. }}$ & $\begin{array}{l}0 \cdot 076 \\
5 \cdot 3\end{array}$ & $\begin{array}{l}0 \cdot 300 \\
5 \cdot 5\end{array}$ & $\begin{array}{l}0 \cdot 85 \\
6 \cdot 1\end{array}$ & $\begin{array}{l}1 \cdot 2 \\
6 \cdot 3\end{array}$ & & \\
\hline
\end{tabular}


regarded as in combination with fixed base and/or ammonia. The titratable acidity in any specimen of urine depends mainly upon the following three variables.

(1) $\mathrm{pH}$. It is clear that the $\mathrm{pH}$-must affect the titratable acidity, for if it is high enough the urine will contain no free acid and there will be nothing to titrate. The effect of pH is shown in table 4 with other $\mathrm{pH}$ effects which will be discussed later. The average titratable acidities of the infant urines show a steady fall as the $\mathrm{pH}$ rises. The differences between the first two pairs of the three adjoining $\mathrm{pH}$ groups were statistically significant $(\mathrm{t}=2 \cdot 01$, $p=0.05 ; t=2 \cdot 22$, $p$ between 0.05 and 0.02 ). The difference between groups 1 and 4 was highly significant $(t=3.2, p$ between 0.01 and 0.001$)$. For adults the differences between all three adjoining groups were statistically significant $(t=3 \cdot 2, p=0 \cdot 01$; $t=3.3$, p between 0.01 and $0.001 ; t=2.75$, $p=0.02$ ). The effect of $\mathrm{pH}$, however, can be completely masked by the other two determinants and should not be considered in practice as the most important of the three.

(2) The concentration of the urine. This is a most important factor in isolated specimens, i.e. when the titratable acid per $100 \mathrm{ml}$. of these specimens is under investigation (see later), but it is probably not so important when the excretion of titratable acid/24 hours is the object of study.

(3) The quantity of phosphates in the urine. (Cushny, 1904; Hendrix and Sanders, 1923-24;
Pitts, 1945a, b; 1946.) This is generally considered to be highly important and phosphates are usually spoken of as the main 'buffer acids' in the urine-(Pitts, 1945a, b). The effect of phosphates seems to be exaggerated when they are given experimentally by injection, for they are then excreted much more rapidly than the accompanying base, and even the alkaline salt $\mathrm{Na}_{2} \mathrm{HPO}$, will greatly increase the titratable acidity of the urine (Cushny, 1904; Hendrix and Sanders, 1923-24). Creatinine also plays a minor rôle as one of the urinary buffer substances (Pitts, 1945a', b).

The ammonia found in the urine is now considered to be made by the kidney from glutamin in the circulating plasma (van Slyke and others, 1943), and to be excreted in response to acid substances left in the tubules after the reabsorption of fixed base (Briggs, 1942). It serves as a measure of this reabsorption, or of the strong acid radicles excreted by the kidney without corresponding fixed base. In other words, it can be taken as a guide to the capacity of the kidney to conserve fixed base.

Table 3 gives information about the acidity titrated to 7.4 and to the phenolphthalein end point, the total nitrogen, the ratio of the total N/acidity titrated to the phenolphthalein end point, the ammonia nitrogen, and the ammonia coefficient (ammonia $\mathbf{N} \times 100 /$ total $\mathbf{N}$ ) in the infant urines and also in the adult specimens. It should be studied in relation to table 1 , which showed the average $\mathrm{pH}$ 's of the urines of the same age groups. It will be

TABLE 3

\begin{tabular}{|c|c|c|c|c|c|c|}
\hline \multirow[b]{2}{*}{ Age } & \multicolumn{2}{|c|}{$\begin{array}{c}\text { Titratable acidity } \\
\text { ml. } 0.01 \text { acid ml. urine }\end{array}$} & \multirow{2}{*}{$\begin{array}{l}\text { Total N } \\
\mathrm{ml} .0 \cdot 01 \\
\mathrm{NH}, \mathrm{OH} / \mathrm{ml} \text {. } \\
\text { of urine }\end{array}$} & \multirow{2}{*}{$\begin{array}{c}\text { Ratio Total } \\
\text { N/acidity } \\
\text { titrated to } \\
\text { phenolphthalein } \\
\text { end point }\end{array}$} & \multirow{2}{*}{$\begin{array}{c}\text { Ammonia } \mathrm{N} \\
\mathrm{ml} .0 \cdot 01 \\
\mathrm{NH}_{4} \mathrm{OH} / \mathrm{ml} . \\
\text { of urine }\end{array}$} & \multirow[b]{2}{*}{$\begin{array}{l}\text { Ammonia } \\
\text { coefficient }\end{array}$} \\
\hline & $\begin{array}{c}\text { to } \\
\text { phenolphthalein } \\
\text { end point }\end{array}$ & $\begin{array}{c}\text { to } \\
\mathrm{pH} 7 \cdot 4\end{array}$ & & & & \\
\hline 0 & $\begin{array}{c}0 \cdot 295 \\
(0 \cdot 14-0 \cdot 74)\end{array}$ & $\begin{array}{c}0 \cdot 13 \\
(0 \cdot 04-0 \cdot 40)\end{array}$ & $\begin{array}{c}4 \cdot 99 \\
(2 \cdot 16-9 \cdot 2)\end{array}$ & $\begin{array}{c}18 \cdot 7 \\
(8 \cdot 9-32 \cdot 6)\end{array}$ & $\begin{array}{c}0 \cdot 410 \\
(0 \cdot 21-0 \cdot 72)\end{array}$ & $\begin{array}{c}8 \cdot 85 \\
(2 \cdot 9-12 \cdot 6)\end{array}$ \\
\hline $5-24 \mathrm{hr}$. & $\begin{array}{c}2 \cdot 62 \\
(1 \cdot 05-5 \cdot 40)\end{array}$ & $\begin{array}{c}1 \cdot 31 \\
(0 \cdot 55-3 \cdot 75)\end{array}$ & $\begin{array}{c}39 \cdot 0 \\
(19 \cdot 1-58 \cdot 8)\end{array}$ & $\begin{array}{c}18 \cdot 3 \\
(5 \cdot 2-40 \cdot 0)\end{array}$ & $\begin{array}{c}3 \cdot 45 \\
(1 \cdot 03-5 \cdot 8)\end{array}$ & $\begin{array}{c}8 \cdot 86 \\
(2 \cdot 8-15 \cdot 2)\end{array}$ \\
\hline 24-72 hr. & $\begin{array}{c}2 \cdot 77 \\
(1 \cdot 20-5 \cdot 50)\end{array}$ & $\begin{array}{l}1 \cdot 51 \\
(0 \cdot 48-3 \cdot 70)\end{array}$ & $\begin{array}{c}51 \cdot 6 \\
(21: 8-97 \cdot 3)\end{array}$ & $\begin{array}{c}20 \cdot 6 \\
(8 \cdot 9-27 \cdot 4)\end{array}$ & $\begin{array}{c}4 \cdot 20 \\
(1 \cdot 70-8 \cdot 20)\end{array}$ & $\begin{array}{c}8 \cdot 1 \\
(5 \cdot 0-12 \cdot 4)\end{array}$ \\
\hline 72 hr. $-4 \frac{1}{2}$ days & $\begin{array}{l}1 \cdot 63 \\
(0 \cdot 35-5 \cdot 90)\end{array}$ & $\begin{array}{c}0 \cdot 85 \\
(0 \cdot 20-3 \cdot 20)\end{array}$ & $\begin{array}{c}28 \cdot 5 \\
(6 \cdot 9-56 \cdot 8)\end{array}$ & $\begin{array}{c}22 \cdot 3 \\
(9 \cdot 2-44 \cdot 6)\end{array}$ & $\begin{array}{c}2 \cdot 19 \\
(0 \cdot 47-7 \cdot 50)\end{array}$ & $\begin{array}{c}8 \cdot 3 \\
(3 \cdot 4-15 \cdot 0)\end{array}$ \\
\hline $4 \frac{1}{2}-6$ days & $\begin{array}{c}0 \cdot 825 \\
(0 \cdot 30-1 \cdot 48)\end{array}$ & $\begin{array}{c}0 \cdot 390 \\
(0 \cdot 15-0 \cdot 65)\end{array}$ & $\begin{array}{c}13 \cdot 7 \\
(6 \cdot 4-27 \cdot 4)\end{array}$ & $\begin{array}{c}18 \cdot 1 \\
(8 \cdot 5-32 \cdot 3)\end{array}$ & $\begin{array}{c}1 \cdot 23 \\
(0 \cdot 41-1 \cdot 95)\end{array}$ & $\begin{array}{c}9 \cdot 8 \\
(5 \cdot 0-16 \cdot 3)\end{array}$ \\
\hline 6-7 days & $\begin{array}{c}1 \cdot 13 \\
(0 \cdot 35-2 \cdot 85)\end{array}$ & $\begin{array}{c}0.58 \\
(0 \cdot 00-1 \cdot 90)\end{array}$ & $\begin{array}{c}23 \cdot 0 \\
(3 \cdot 26-52 \cdot 0)\end{array}$ & $\begin{array}{c}23 \cdot 2 \\
(9 \cdot 3-54 \cdot 2)\end{array}$ & $(0 \cdot 27-3 \cdot 40)$ & $\begin{array}{c}7 \cdot 7 \\
(4 \cdot 0-11 \cdot 3)\end{array}$ \\
\hline 7 days and over & $\begin{array}{l}0 \cdot 86 \\
(0 \cdot 30-1 \cdot 75)\end{array}$ & $\begin{array}{c}0.32 \\
(0 \cdot 00-1 \cdot 10)\end{array}$ & $\begin{array}{c}15 \cdot 10 \\
(6 \cdot 4-27 \cdot 6)\end{array}$ & $\begin{array}{c}20 \cdot 6 \\
(10 \cdot 9-45 \cdot 6)\end{array}$ & $\begin{array}{c}1 \cdot 13 \\
(0 \cdot 39-2 \cdot 75)\end{array}$ & $\begin{array}{l}7 \cdot 6 \\
(1 \cdot 9-11 \cdot 0)\end{array}$ \\
\hline Adults & $\begin{array}{c}3 \cdot 05 \\
(0 \cdot 60-10 \cdot 4)\end{array}$ & $(0 \cdot 00-7 \cdot 20)$ & $\begin{array}{c}46 \cdot 5 \\
(18 \cdot 7-107 \cdot 0)\end{array}$ & $\begin{array}{c}21 \cdot 4 \\
(4 \cdot 81-69 \cdot 3)\end{array}$ & $\begin{array}{c}2 \cdot 59 \\
(0 \cdot 30-7 \cdot 80)\end{array}$ & $\begin{array}{c}5 \cdot 90 \\
(0 \cdot 8-15 \cdot 6)\end{array}$ \\
\hline
\end{tabular}


seen at once that there was a great change in the titratable acidity of the urines soon after birth. From $0.295 \mathrm{ml}$. $0.01 \mathrm{~N} \mathrm{NaOH} / \mathrm{ml}$. of urine secreted in utero, it rose to $2.77 \mathrm{ml}$. between the twenty-fourth and seventy-second hours of life, and thereafter fell to a level of about $1 \mathrm{ml}$. If all the children are taken together it can easily be shown, as might have been expected, that the titratable acidity fell as the $\mathrm{pH}$ rose (see table 4 ), but the small changes in the $\mathrm{pH}$ of the urines of the different age groups (see table 1) were not responsible for the large changes in titratable acidity shown in table 3. These were mainly the result of changes in the concentration of the urine. This is shown by the figures for total $\mathrm{N}$ and for the ratio of titratable acidity to total $\mathrm{N}$. If the total $\mathrm{N}$ be taken as a measure of the concentration of the urine, then it will be seen from table 3 that the titratable acidity varied with it, for the ratio of the total $\mathrm{N} /$ titratable acidity changed very little and in no consistent direction in spite of fluctuations in the quantity of total $\mathrm{N}$ per $\mathrm{ml}$. of urine. These changes were due to the fact that the urine passed in utero was extremely dilute, whereas that passed during the first seventy-two hours of life was much more concentrated owing to the child being dehydrated at that time. The urines passed later in the first week of life were again more dilute (Heller, 1944; Thomson, 1944). It will also be noticed that, even when the infants were dehydrated and the titratable acidities were at their highest, the average value was lower than the mean for the whole group of adults, many of whose urines were, for adults, quite dilute, This is a demonstration of the fact that a baby is incapable of producing a urine with an osmotic pressure equal to that which an adult can produce under comparable conditions. Most of the concentrated adult urines had titratable acidities above $5 \mathrm{ml}$. of $0.01 \mathrm{~N} \mathrm{NaOH}$ per ml. of urine. The inability of a baby to produce a concentrated urine, however (see p. 202), may not be the only reason why the titratable acidities of the infants tended to be so much lower than those of the adults.

The ammonia found in the urine of the infants in the different age groups is given in the penultimate column of table 3 . It will be seen that the average values fluctuated with the age of the children, as did the titratable acidities and the total nitrogensand for the same reason. The ammonia coefficients did not vary in any consistent direction with age during the first week of life; but they were, in all the age groups, higher than the average value for the whole group of adults. Brock and Hofman (1930) came to the conclusion that the ammonia coefficients of infants were high, but their work was done on babies older than those in the present series. Landsberger (1925b) has reported on one baby aged one day with an ammonia coefficient of $2 \cdot 6$, and Hottinger and Hottinger (1932) gave a very low figure for the ammonia excretion of a baby in the first few days of life, but no conclusions can be drawn from single cases. Taking the children as one group and the adults as another, the average coefficient for the babies was $8 \cdot 466, \sigma=3 \cdot 34$ and for the adults $5 \cdot 40, \sigma=2 \cdot 71$. The difference between the ammonia coefficients at the two ages was highly significant $(t=5 \cdot 10, p=<0 \cdot 001)$, and the histiograms of the relationship are shown in fig. 2. There is reason to believe that the urine of
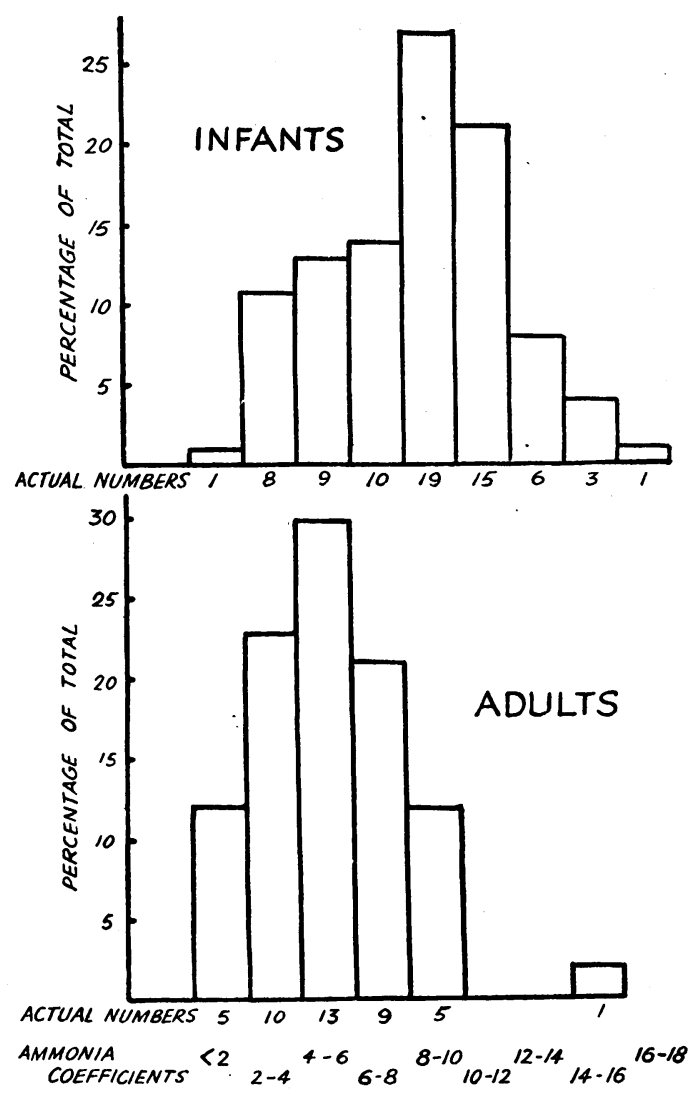

Fig. 2.-Frequency distribution diagrams of the ammonia coefficients.

infants may contain nitrogenous substances which do not appear in an adult's urine and that, therefore, the total nitrogen of an infant's urine may not be the metabolic equivalent of the total nitrogen of an adult's urine. The urea certainly forms a surprisingly small percentage of the total nitrogen in an infant's urine (Simon, 1911; and observations to be published), and had the relationship under discussion been based upon the ratio of the ammonia/ammonia + urea, there would have been a larger difference between the infants and the adults. The $\mathbf{N}$ partition in the urine of infants is under investigation. Henderson and Palmer (1914) came to the conclusion that the daily excretion of ammonia was little affected by the $\mathrm{pH}$ of the twenty-four-hour specimens, but Eggleton (1946) came to essentially 
the opposite conclusion, which seems a more reasonable one. Hubbard (1923-24) considered that there was a closer correlation between the $\mathrm{pH}$ of the urine and the concentration of ammonia in it than there was between the $\mathrm{pH}$ and the quantity of ammonia excreted or the ammonia coefficient. It may be shown from the present data (see table 4)

TABLE 4

THE EFFECT OF $p H$ UPON THE URINARY ACIDITY, TITRATED TO pH $8 \cdot 3$, THE AMMONIA COEFFICIENT, AND THE $\mathrm{NH}_{3} / \mathrm{ACIDITY}$ TITRATED TO $\mathrm{pH} 7 \cdot 4$ AND $8 \cdot 3$ OF INFANTS AND ADULTS

Infants

\begin{tabular}{|c|c|c|c|c|}
\hline $\begin{array}{l}\text { Number in } \\
\text { group }\end{array}$ & $\begin{array}{c}\text { Group } 1 \\
\text { up to } \\
\text { pH } 5 \cdot 5 \\
18\end{array}$ & $\begin{array}{c}\text { Group } 2 \\
\text { pH } 5 \cdot 6 \\
- \text { pH } 6 \\
21\end{array}$ & $\begin{array}{c}\text { Group } 3 \\
\text { pH 6.1 } \\
\text {-pH 6.6 } \\
22\end{array}$ & $\begin{array}{c}\text { Group } 4 \\
\text { pH } 6 \cdot 7 \\
\text { and over } \\
11\end{array}$ \\
\hline $\begin{array}{l}\text { Titratable } \\
\text { acidity to } \\
\text { phenolphtha- } \\
\text { lein end point }\end{array}$ & $\begin{array}{r}2.48 \\
\sigma=1.95\end{array}$ & $\sigma=\begin{array}{r}1.52 \\
0.93\end{array}$ & $\sigma=\begin{array}{r}0.95 \\
0.76\end{array}$ & $\begin{array}{r}0 \cdot 58 \\
\sigma=0 \cdot 38\end{array}$ \\
\hline $\begin{array}{l}\mathrm{NH}_{3} \text { coeffi- } \\
\text { cient }\end{array}$ & $\begin{array}{r}9 \cdot 41 \\
\sigma=3 \cdot 1\end{array}$ & $\begin{array}{r}8 \cdot 74 \\
\sigma=2 \cdot 89\end{array}$ & $\sigma=\begin{array}{r}8 \cdot 62 \\
2 \cdot 98\end{array}$ & $\begin{aligned} & 5 \cdot 8 \\
\sigma= & 4 \cdot 18\end{aligned}$ \\
\hline $\begin{array}{l}\mathrm{NH}_{3} / \text { tit. } \\
\text { acidity to } \mathrm{pH} \\
7 \cdot 4^{*}\end{array}$ & $\sigma=\begin{array}{r}2 \cdot 03 \\
0.87\end{array}$ & $\sigma=\begin{array}{r}3 \cdot 46 \\
\sigma \cdot 38\end{array}$ & $\sigma=2 \cdot 08$ & $\sigma=\begin{array}{r}6 \cdot 47 \\
1 \cdot 55\end{array}$ \\
\hline $\begin{array}{l}\mathrm{NH}_{3} / \text { tit. } \\
\text { acidity to } \\
\text { phenolphtha- } \\
\text { lein end point }\end{array}$ & $\sigma=0 \cdot 32$ & $\sigma=\begin{array}{r}1 \cdot 62 \\
0.45\end{array}$ & $\sigma=\begin{array}{r}1 \cdot 60 \\
0.50\end{array}$ & $\sigma=\begin{array}{r}1 \cdot 54 \\
0 \cdot 40\end{array}$ \\
\hline
\end{tabular}

Adults

\begin{tabular}{|c|c|c|c|c|}
\hline $\begin{array}{l}\text { Number in } \\
\text { group }\end{array}$ & $\begin{array}{c}\text { Group } 1 \\
\text { up to } \\
\text { pH 5.0 } \\
5\end{array}$ & $\begin{array}{c}\text { Group } 2 \\
\text { pH 5.1 } \\
-5 \cdot 9 \\
\\
14\end{array}$ & $\begin{array}{c}\text { Group } 3 \\
\text { pH 6.0 } \\
-6 \cdot 9 \\
16\end{array}$ & $\begin{array}{c}\text { Group 4 } \\
\text { pH } 7 \\
\text { and over } \\
8\end{array}$ \\
\hline $\begin{array}{l}\text { Titratable } \\
\text { acidity to } \\
\text { phenolphtha- } \\
\text { lein end point }\end{array}$ & $\begin{array}{r}6 \cdot 70 \\
\sigma=2 \cdot 30\end{array}$ & $\begin{array}{r}3.95 \\
\sigma=1.50\end{array}$ & $\begin{array}{r}2 \cdot 23 \\
\sigma=1 \cdot 39\end{array}$ & $\begin{array}{r}0.84 \\
\sigma=0.39\end{array}$ \\
\hline $\begin{array}{l}\mathrm{NH}_{3} \text { coeffiv } \\
\text { cient }\end{array}$ & $\begin{array}{r}9 \cdot 88 \\
\sigma=3 \cdot 16\end{array}$ & $\sigma=\begin{array}{r}6 \cdot 33 \\
\sigma \cdot 22\end{array}$ & $\begin{array}{r}4 \cdot 25 \\
\sigma=1 \cdot 59\end{array}$ & $\begin{array}{r}2 \cdot 27 \\
\sigma=1 \cdot 12\end{array}$ \\
\hline $\begin{array}{l}\mathrm{NH}_{3} / \text { tit. } \\
\text { acidity to } \mathrm{pH} \\
7 \cdot 4^{*}\end{array}$ & $\sigma=0.31$ & $\sigma=\begin{array}{r}1 \cdot 31 \\
0 \cdot 35\end{array}$ & $\begin{array}{r}1.99 \\
\sigma=1.17\end{array}$ & $\begin{array}{r}7 \cdot 24 \\
\sigma=3 \cdot 90\end{array}$ \\
\hline $\begin{array}{l}\mathrm{NH}_{3} / \text { tit. } \\
\text { acidity to } \\
\text { phenolphtha- } \\
\text { lein end point }\end{array}$ & $\begin{array}{r}0.89 \\
\sigma=0.10\end{array}$ & $\begin{array}{r}0.86 \\
\sigma=0 \cdot 15\end{array}$ & $\begin{array}{r}0.83 \\
\sigma=0.16\end{array}$ & $\begin{array}{r}0.89 \\
\sigma=0.41\end{array}$ \\
\hline
\end{tabular}

* Omitting all urines from group 4 with $\mathrm{pH}=$ or $>7 \cdot 4$. that the ammonia coefficient fell both in infants and adults as the $\mathrm{pH}$ rose. The differences between the adult groups were all statistically significant. When the group up to and including $\mathrm{pH} 5.0$ was compared with the next group, $t=3 \cdot 58$, and $p$ was $<0 \cdot 01$, and when the pH $5 \cdot 1$ to 5.9 group was compared with the pH 6-6.9 group $t=4.07$ and $p<0.01$. For the two most alkaline groups $t=3 \cdot 2$ and $p 0 \cdot 01$. The differences between the adjoining groups of the infants were not statistically significant, but the difference between the most acid and most alkaline group was significant $\left(t=2.77\right.$ with $\mathrm{p}^{\circ}$ between 0.01 and 0.02). There can be little doubt that at all ages the more acid the urine the more of the total nitrogen tends to be excreted as ammonia.

The present results do not support the old German contention (Simon, 1911; Landsberger, 1925a) that the urine contains very little ammonia for a day or two after birth, or that the ammonia coefficient is extremely low till the meconium has been passed, and then rises gradually as the flow of milk is established and bacterial fermentation in the gut produces organic acids to be excreted by the kidney.

The ratio of the ammonia to the titratable acidity. Early workers usually measured the titratable acidity by titrating the urine to the phenolphthalein end point, but later it appeared more physiological to most workers to titrate to $\mathrm{pH} 7.4$ which is the approximate $\mathrm{pH}$ of the blood (Henderson and Palmer, 1914, 1915). Some have continued to titrate to $\mathrm{pH} \mathrm{8.2}$ (Landsberger, 1925a, b; Eggleton, 1946) and Maizels and McArthur (1928-29) changed their end point from $\mathrm{pH} 7 \cdot 4$ to the phenolphthalein change. For anyone interested in the ammonia/ titratable acid ratio, there is a sound reason for preferring the phenolphthalein end point to $7 \cdot 4$. Ammonia continues to be excreted in the urine, although in smaller amounts, even at $\mathrm{pH}$ values above $7 \cdot 4$; and consequently the ratio of the urinary ammonia to the acidity titrated to $7 \cdot 4$ rises with the $\mathrm{pH}$ and becomes infinity at 7.4. Table 4 shows this effect of $\mathrm{pH}$. The difference between groups 1 and 2 for the babies was highly significant $(t=3 \cdot 80$, $p=0.001$ ), the differences between groups 2 and 3 and 3 and 4 were also significant $(t=2 \cdot 52, p=0.02$; $t=2 \cdot 05, p=0 \cdot 05)$. The difference between groups 2 and 4 was highly significant $(t=5 \cdot 07, p=<0 \cdot 001)$ The difference between the adult groups 2 and $\dot{3}$ was significant $(t=2.09, p$ between 0.05 and 0.02$)$; that between the groups 3 and 4 was highly significant $(t=4 \cdot 96, p=<0 \cdot 001)$. This drift of the ratio with the $\mathrm{pH}$ would have been a great disadvantage in the present investigation in which it - was proposed to compare the ratio in a group of infants and adults, for, although the average $\mathrm{pH}$ of the two groups was almost the same, the scatter was not (table 1). If, however, the urine is titrated to the phenolphthalein end point, for some reason, which may turn out to be of physiological importance, the ratio becomes independent of $\mathrm{pH}$ both in adults and infants (table 4), and, therefore, the 
two ages may justifiably be compared. The ratio in adults averaged $0.86(\sigma=0.21)$ and in infants generally exceeded the titratable acidity, and this is in agreement with a few findings of Brock and Hofman (1930) in older infants. The difference between 0.86 and 1.48 was highly significant $(t=7 \cdot 7, p=<0 \cdot 001)$ and the histograms are given in fig. 3. These results show that, of the total acid $1.48(\sigma=0 \cdot 50)$. In infancy, therefore, the ammonia

no doubt that there are big differences between the two ages in the way in which they excrete phosphates. The urine in infancy may contain practically no phosphates. Figures below $1 \mu \mathrm{g}$. per $\mathrm{ml}$. of urine were obtained on three of the children. The highest figure was $780 \mu \mathrm{g}$. per $\mathrm{ml}$. but this was quite exceptional and there were only two others over $400 \mu \mathrm{g}$. per $\mathrm{ml}$. There seem very few figures in the literature with which to compare these. Maizels and McArthur (1928-29) found urinary phosphates in older and frequently pathological children to range from 0.045 per cent. to 1.46 per cent. as $\mathbf{P}_{2} \mathbf{O}_{5}$. They stated that 0.3 per cent. was about the upper limit of normality. Branning (1942) found the urine of a group of premature but 'older' babies to contain 0.33 to $1.8 \mathrm{~g}$. of phosphorus per litre. These figures seem high, but the results may be expressed as $\mathrm{P}_{2} \mathrm{O}_{5}$ and the children were not really comparable with those in the present series. The average amount of phosphorus found in the infants' urines was $74.4 \mu \mathrm{g}$. per $\mathrm{ml}$. and this is to be compared with 613.6 $\mu \mathrm{g}$. per $\mathrm{ml}$. in the adult urines. This difference, however, was largely due to the urine being so much more dilute in infancy. All the urinary constituents were present in smaller concentrations (compare the titratable acidity and total nitrogen). So far as phosphorus is concerned a much more valuable comparison between the infants and adults may be made by considering the $\mathbf{P} / \mathbf{N}$ ratios. This virtually eliminates the differences due to the dilution. The ratio averaged 2.92 for the whole series of infant urines

which is excreted by the kidney uncombined with fixed base, a higher proportion tends to be combined with ammonia in infancy than in adult life, and a smaller proportion to be found as free titratable acid. An explanation of why this should be so will now be given.

The excretion of phosphates. Phosphates do not stimulate the kidney to excrete ammonia (Marriott and Howland, 1918); but they may, as already stated, contribute a great deal towards the magnitude of the titratable acidity (Pitts, 1945a, b). It was natural, therefore, to look into the excretion of phosphates in newborn children and to compare the findings with those of adults. The percentage of phosphates in adult urines, and the phosphate clearances, have been found by others to be very variable and to be subject to unknown laws (Ollayos and Winkler, 1943; Pitts and Alexander, 1944). This has to some extent been confirmed, and it has been found to be true also of infants, but there is 
acidity due to organic acids tended to be very high in these infants. Hottinger (1925) found the 'organic acids' excreted per kilo of body weight to be higher in infants than in adults, but his only figures for two babies with ages similar to those of the present series were within the adult range. His data, however, are not really comparable. The nature of these 'organic acids' or organic buffer substances is obscure, but it is possible that an examination of the "undetermined $\mathbf{N}$ ' in infant urines, which has now been undertaken, may help to solve the problem. It will be clear from previous work (Marriott and Howland, 1918; Pitts, 1945a, b) and from what has already been said, that the small amounts of phosphates available for excretion in infancy may limit very materially the amount of free acid which their kidneys can excrete, and this no doubt explains, in part at any rate, why the ammonia coefficients are so high, for in the absence of buffer substances in the urine there would naturally be a tendency for acid substances to be excreted in combination with ammonia. If, moreover, it is correct that infants are in a state of acidosis during the early days of life (Ylppö, 1916, 1923-24; Seham, 1919; Hoag and Kiser, 1931 ; Branning, 1942), the acidosis may be explained by the paucity of phosphates available for excretion, for without them the ability of the kidney to excrete acids, and so to correct an acidosis, must be curtailed (Pitts, 1945 b, 1946).

Ketosed adults. The urines of ketosed adults make an interesting comparison with those of normal infants. Only ten have been obtained, but they are enough to bring out certain resemblances and differences. The data are set out in table 5 . The urines of the adults who were ketosed had, as might have been expected, a lower average $\mathrm{pH}$ than those of the infants or of the normal adults. The total nitrogen in these urines was slightly higher than that of the normal adults, but this difference was not significant. The titratable acidity was slightly higher, and the phosphorus considerably lower. This led to a $\mathrm{P} / \mathrm{N}$ ratio approximating to that of the infants, and meant that the percentage of the titratable acidity due to organic acids was higher than the adult normal and near the average for the infants. Thus the urines of the normal infants resembled in composition those of adults who were suffering from acidosis. The ammonia coefficients and the ratios of ammonia/titratable acidity of the ketosed adults were much higher than those of the normal adults and higher than

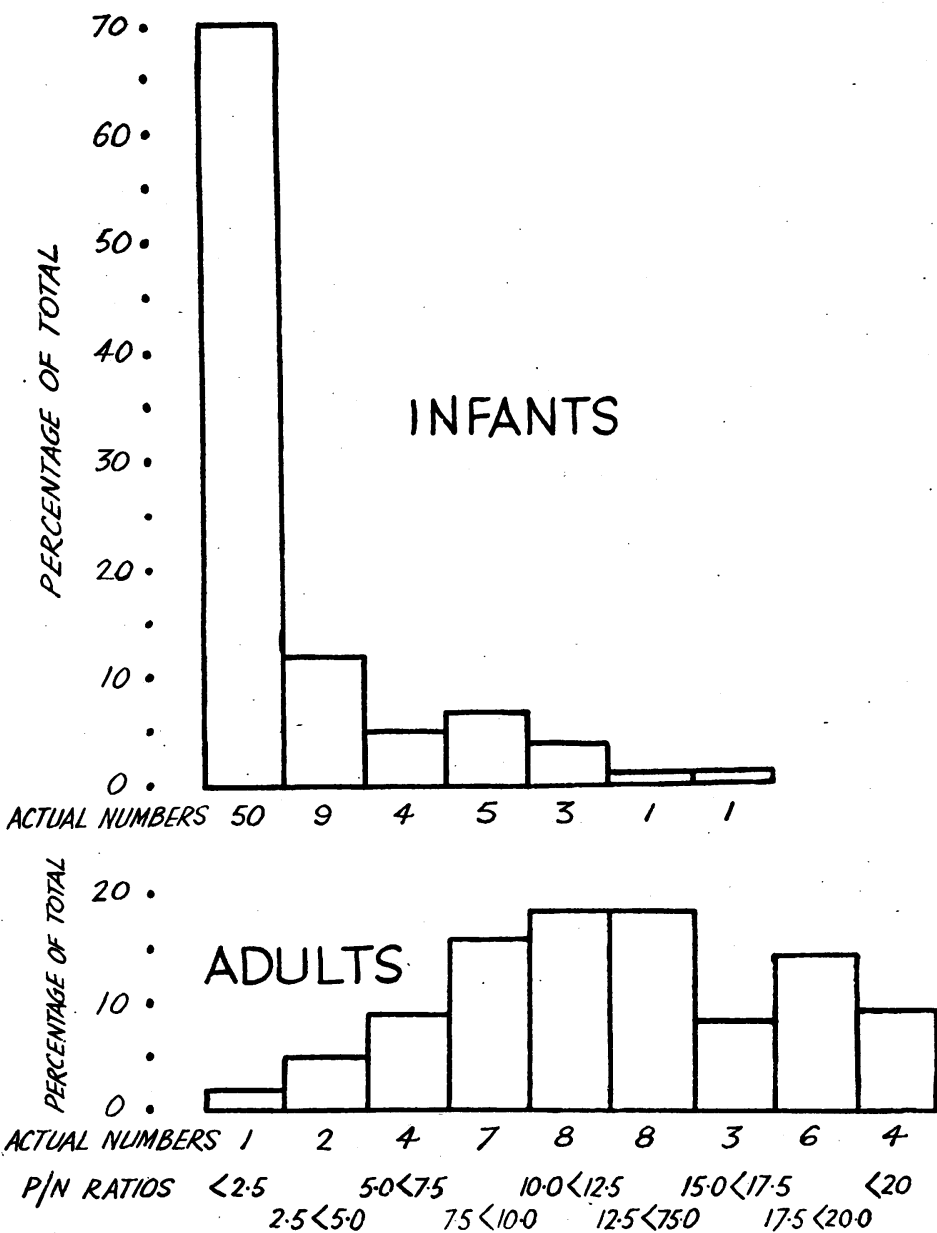

FIG. 4.-Frequency distribution diagrams of the $\mathrm{P} / \mathrm{N}$ ratios.

those of the infants. In both instances the average for the infants fell between the normal adults and the ketosed adults. This indicates that, so far as the formation and excretion of ammonia were concerned, the infants were again reacting as though they were adults with an acidosis, but the same result might equally well be attributed to a deficiency of phosphorus available for excretion.

The present results do not prove that the infants were in a state of acidosis. The $\mathrm{pH}$ of their urines, indeed, suggests that they were no more acidosed than normal adults. It is clear, however, that they were excreting so little phosphorus in their urines that their kidneys were forced to react in other ways as though they had an acidosis. It is also clear. 
that, if for any reason infants were to acquire an acidosis, the small amount of phosphorus available for excretion would greatly limit the capacity of their kidneys to correct it.

Foetal urine. Considerable interest is attached to the composition of urine secreted by the kidney
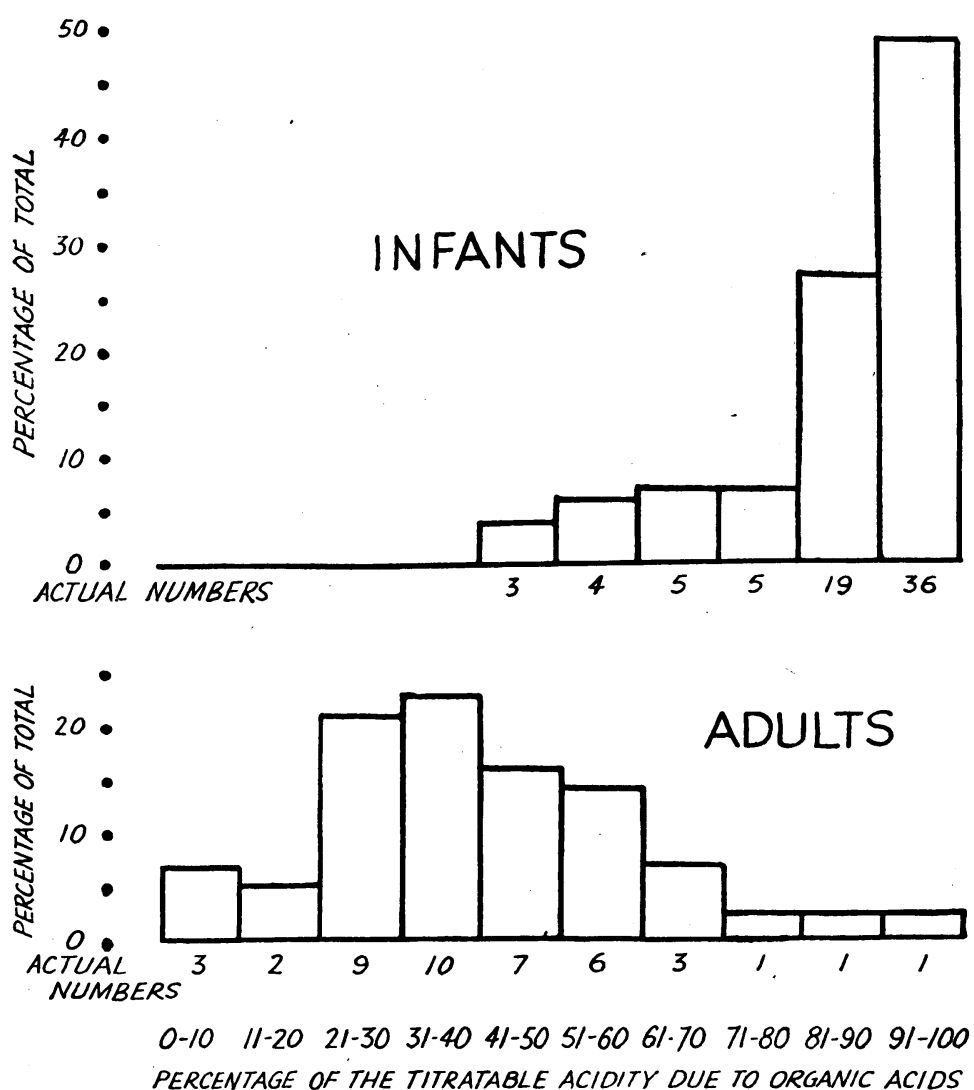

FIG. 5.-Frequency distribution diagrams of the percentage of the titratable acidity (end point $\mathrm{pH} 8 \cdot 3$ ) due to organic acids. cent.; the titratable acidity to phenolphthalein was 0.295 and the ammonia coefficient $8 \cdot 85$. The phosphorus averaged $6 \cdot 16 \mu \mathrm{g}$. per $\mathrm{ml}$. and the $\mathrm{P} / \mathrm{N}$ ratio $1 \cdot 22 ; 88 \cdot 4$ per cent. of the titratable acidity was due to organic acids. In all these respects the foetal urines resembled the urines passed by the babies after birth and differed only in greater dilution. It is hoped to make a much more complete study of urine passed by full-term infants while they are still in utero.

\section{Summary}

1. The average $\mathrm{pH}$ of infant urines tended to fall slightly after birth and rose again as the flow of milk became established. These differences were not statistically significant. The average $\mathrm{pH}$ of seventy-two newborn urines was almost the same as that of a collection of forty-three urines from healthy adults.

2. The acidity titrated to the phenolphthalein end point and the ammonia $\mathbf{N}$ of infant urines rose and fell with the total $\mathrm{N}$, that is to say, with the concentration of the urines. They were, therefore, affected by the age of the children and were highest between the fifth and seventysecond hours of life. The titratable acidity fell as the $\mathrm{pH}$ rose.

3. The ammonia coefficients were unaffected by age, fell as the $\mathrm{pH}$ rose, and on each of the first seven days of life averaged more than those of normal adults.

in utero. It has been studied previously by Guthmann and May (1930) and by Tausch (1936). The latter catheterized a large number of babies at birth and made a great many observations on the colour, reaction, specific gravity, and total nitrogen. With his results the present data are in substantial agreement. The striking thing about these urines is their high dilution and low specific gravity. These may be due to the imbibition of liquor amnii (Smith, 1945), but in any event they are to be contrasted most strongly with the maternal urines, and with the urines passed by the same children twenty-four to forty-eight hours later. Tausch found the average total nitrogen to be 0.155 per cent., which seems very low in comparison with the specific gravities which he reported. The average total $\mathrm{N}$ for the present series of ten was 0.075 per
4. The ratio of the ammonia to the acidity, titrated to the phenolphthalein end point, was unaffected by $\mathrm{pH}$ in both infants and adults and tended to be considerably higher in the former than in the latter.

5. The urines of newborn children contained very little phosphate and the phosphorus/nitrogen ratios were low by adult standards. In consequence of the small phosphate excretion the percentages of the titratable acidities due to organic acids were very high, much higher than in adults.

6. In their ammonia coefficients, ammonia/ titratable acid ratios and $P / N$ ratios, and in the percentages of the titratable acidity due to organic acids, the urines of newborn infants have been found 
TABLE 5

A COMPARISON OF THE URINES OF KETOSED ADULTS WITH THOSE OF INFANTS AND NORMAL ADULTS

\begin{tabular}{|c|c|c|c|}
\hline & \multirow{2}{*}{ Infants } & \multicolumn{2}{|c|}{ Adults } \\
\hline & & Ketosed & Normal \\
\hline$\cdots \quad \ldots$ & $\begin{array}{c}5 \cdot 96 \\
\sigma=0 \cdot 63\end{array}$ & $\begin{array}{c}5 \cdot 4 \\
\sigma=0.53\end{array}$ & $\begin{array}{c}6 \cdot 11 \\
\sigma=0 \cdot 83\end{array}$ \\
\hline $\begin{array}{l}\text { Titratable acidity to the } \\
\text { phenolphthalein end } \\
\text { point ml. } 0 \cdot 01 \mathrm{~N} \\
\text { acid/ml. urine. }\end{array}$ & $\begin{array}{c}1 \cdot 44 \\
\sigma=1 \cdot 33\end{array}$ & $\begin{array}{c}3 \cdot 23 \\
\sigma=0 \cdot 94\end{array}$ & $\begin{array}{c}3 \cdot 05 \\
\sigma=2 \cdot 23\end{array}$ \\
\hline $\begin{array}{l}\text { Total } \mathrm{N} \text { ml. } 0 \cdot 01 \mathrm{~N} \\
\mathrm{NH}_{4} \mathrm{OH} / \mathrm{ml} . \text { urine. }\end{array}$ & $\begin{array}{c}25 \cdot 0 \\
\sigma=19 \cdot 7\end{array}$ & $\begin{array}{c}50 \cdot 3 \\
\sigma=29 \cdot 9\end{array}$ & $\begin{array}{c}46 \cdot 5 \\
\sigma=19 \cdot 7\end{array}$ \\
\hline Ammonia coefficient & $\begin{array}{c}8 \cdot 47 \\
\sigma=3 \cdot 34\end{array}$ & $\begin{array}{c}13 \cdot 9 \\
\sigma=9 \cdot 0\end{array}$ & $\begin{array}{c}5 \cdot 4 \\
\sigma=2 \cdot 71\end{array}$ \\
\hline $\begin{array}{l}\text { Ammonia/acidity } \\
\text { titrated to the phenol- } \\
\text { phthalein end point }\end{array}$ & $\begin{array}{c}1 \cdot 48 \\
\sigma=0 \cdot 50\end{array}$ & $\begin{array}{c}2 \cdot 07 \\
\sigma=1 \cdot 34\end{array}$ & $\begin{array}{c}0.86 \\
\sigma=0 \cdot 21\end{array}$ \\
\hline Phosphorus $\mu$ g. per $\mathrm{ml}$. & $\begin{array}{c}74 \cdot 4 \\
\sigma=134 \cdot 5\end{array}$ & $\begin{array}{c}323 \\
\sigma=274\end{array}$ & $\begin{array}{c}614 \\
\sigma=316\end{array}$ \\
\hline $\mathbf{P} / \mathbf{N}$ ratio & $\begin{array}{c}2 \cdot 92 \\
\sigma=3 \cdot 8\end{array}$ & $\begin{array}{c}7 \cdot 11 \\
\sigma=5 \cdot 73\end{array}$ & $\begin{array}{c}12 \cdot 64 \\
\sigma=6 \cdot 1\end{array}$ \\
\hline $\begin{array}{l}\% \text { of titratable acidity } \\
\text { due to organic acids }\end{array}$ & $\begin{array}{c}86 \cdot 2 \\
\sigma=15 \cdot 0\end{array}$ & $\begin{array}{c}70 \cdot 1 \\
\sigma=20 \cdot 5\end{array}$ & $\begin{array}{c}42 \cdot 1 \\
\sigma=18 \cdot 8\end{array}$ \\
\hline
\end{tabular}

to resemble those of ketosed adults. This does not necessarily mean that the infants were suffering from acidosis, for the resemblances might equally well have been brought about by the small amounts of phosphorus available for excretion.

7. The small amount of phosphate normally excreted by the kidney would, however, severely limit the capacity of infants to deal with an acidosis if they had one.

8. Urine passed in utero is highly dilute, but differs in no other ways so far discovered from urine passed in the first few days of life.

The authors are indebted to Prof. K. J. Anselmino for allowing them to make use of the facilities at the Landesfrauenklinik, Wuppertal. Dr. R. F. A. Dean very kindly catheterized the babies and carried out the two experiments shown in table 2, and Dr. E. M. Widdowson has been a great help on many occasions.
REFERENCES

Branning, W. S. (1942). J. clin. Invest., 21, 101.

Brock, J. and Hofman, A. (1930). Z. Kinderheilk., 48, 585

Briggs, A. P. (1922). J. biol. Chem., 53, 13.

- (1942). J. Lab. clin. Med., 28, 174.

Carr, A. D. (1921). J. Pharm. exp. Therap., 18, 221.

Conway, E. J. (1935). Biochem. J., 29, 2755.

C and Byrne, A. (1933). Ibid., 27, 419.

Cushny, A. R. (1904). J. Physiol., 31, 188.

Dean, R. F. A. and McCance, R. A. (1947). Ibid., 106, 431 .

Eggleton, M. G. (1946). I Ibid., 104, 312.

Fiske, C. H. and Subberow, Y. (1925). J. biol. Chem., 66, 375 .

Guthmann, H. and May, W. (1930). Arch. Gynäk., 141, 450.

Heller, H. (1944). J. Physiol., 102, 429.

Henderson, L. J. and Palmer, W. W. (1914). J. biol. Chem., 17, 305.

- (1915). Ibid., 21, 37.

Hendrix, B. M. and Sanders, J. P. (1923-24). Ibid., 58, 503.

Hoag, L. A. and Kiser, W. H. (1931). Amer. J. Dis. Child., 41, 1054.

Hottinger, A. (1925). Mschr. Kinderheilk., 30, 497.

- and Hottinger, G. (1932). Ibid., 52, 204.

Hubbard, R. S. (1923-24). J. biol. Chem., 58, 711.

Landsberger, M. (1925a). Z. Kinderheilk., 39, 586.

- (1925b). Ibid., 39, 597.

Lee, M. H. and Widdowson, E. M. (1937). Biochem. J., 31, 2035.

Lucas, W. P., Dearing, B. F., Hoobler, H. R., Cox, A., Jones, M. R. and Smyth, F. S. (1921). Amer. J. Dis. Child., 22, 525.

Maizels, M. and McArthur, C. B. (1928-29). Quart. J. Med., 22, 581.

Marples, E. and Lippard, V. W. (1932). Amer. J. Dis. Child., 44, 31 .

__ (1933). Ibid., 45, 294.

Marriott, W. M. and Howland, J. (1918). Arch. intern. Med., 22, 477.

McCance, R. A. (1946). Schweiz. med. Wschr., 76, 857. and Wilkinson, E. (1947). J. Physiol., 106, 256.

Ollayos, R. W. and Winkler, A. W. (1943). J. clin. Invest., 22, 147.

Pitts, R. F. (1945a). Science, 102, 49.

(1945b). Ibid., 102, 81 .

(1946). Ann. Rev. Physiol., 8, 199. and Alexander, R. S. (1944). Amer. J. Physiol., 142, 648.

Rüdel, G. (1892). Arch. exp. Path. Pharmakol., 30, 41.

Seham, M. (1919). Amer. J. Dis. Child., 18, 42.

Simon, S. (1911). Z. Kinderheilk., 2, 1.

Slyke, D. D. van; Phillips, R. A., Hamilton, P. B., Archibald, R. M., Futcher, P. H., and Hiller, A. (1943). J. biol. Chem., 150, 481.

Smith, C. A. (1945). The physiology of the newborn infant. Springfield, Illinois. Charles C. Thomas.

Tausch, M. (1936). Arch. Gynäk., 162, 217.

Thomson, J. (1944). Arch. Dis. Childh., 19, 169.

Veil, W. H. (1923). Ergebn. inner. Med. Kinderheilk., 23, 648 .

Ylppö, A. (1916). Z. Kinderheilk., 14, 268.

(1923-24). Acta Paediatr. Stockh., 3, 235. 